\title{
Monitoring Granule Formation in Anaerobic Upflow Bioreactors Using Oligonucleotide Hybridization Probes
}

\author{
D. Zheng, ${ }^{1}$ L.T. Angenent, ${ }^{2}$ L. Raskin ${ }^{3}$ \\ ${ }^{1}$ Department of Civil and Environmental Engineering, \\ University of Illinois at Urbana-Champaign, Urbana, Illinois \\ ${ }^{2}$ Environmental Engineering Science Program, Department of Chemical Engineering, \\ Washington University in St. Louis, St. Louis, Missouri \\ ${ }^{3}$ Department of Civil and Environmental Engineering, University of Michigan, \\ 107 EWRE Building, 1351 Beal Avenue, Ann Arbor, Michigan 48109-2125; \\ telephone: 734-647-6920; fax: 734-763-2275; e-mail: raskin@umich.edu
}

Received 17 June 2005; accepted 27 December 2005

Published online 20 April 2006 in Wiley InterScience (www.interscience.wiley.com). DOI: 10.1002/bit.20870

\begin{abstract}
The process of granule formation in upflow anaerobic sludge blanket (UASB) reactors was studied using oligonucleotide hybridization probes. Two laboratory-scale UASB reactors were inoculated with sieved primary anaerobic digester sludge from a municipal wastewater treatment plant and operated similarly except that reactor $\mathrm{G}$ was fed glucose, while reactor GP was fed glucose and propionate. Size measurements of cell aggregates and quantification of different populations of methanogens with membrane hybridization targeting the small-subunit ribosomal RNA demonstrated that the increase in aggregate size was associated with an increase in the abundance of Methanosaeta concilii in both reactors. In addition, fluorescence in situ hybridization showed that the major cell components of small aggregates collected during the early stages of reactor startup were $M$. concilii cells. These results indicate that $M$. concilii filaments act as nuclei for granular development. The increase in aggregate size was greater in reactor GP than in reactor $\mathrm{G}$ during the early stages of startup, suggesting that the presence of propionateoxidizing syntrophic consortia assisted the formation of granules. The mature granules formed in both reactors exhibited a layered structure with $M$. concilii dominant in the core, syntrophic consortia adjacent to the core, and filamentous bacteria in the surface layer. The excess of filamentous bacteria caused delay of granulation, which was corrected by increasing shear through an increase of the recycling rate. (c) 2006 Wiley Periodicals, Inc.
\end{abstract}

Keywords: granules; upflow anaerobic sludge blanket reactor; UASB; methanogens; syntrophic propionate oxidizers; oligonucleotide hybridization probes; Methanosaeta concilii; fluorescence in situ hybridization; FISH

\section{INTRODUCTION}

Biomass is maintained in anaerobic wastewater treatment systems as dispersed sludge, as biofilms attached to support material, or as granular sludge. Granular sludge consists of

Correspondence to: Dr. L. Raskin

Contract grant sponsor: Center for Advanced Study and Critical Research Initiative, University of Illinois conglomerates of anaerobic microorganisms, which are still visible as separate entities after settling (Dubourguier et al., 1987). In contrast to biofilms, granular sludge forms without the presence of a support material. Granular sludge exhibits a higher settling ability, higher treatment efficiency due to low mass-transfer limitations for intermediates and favorable micro-environmental conditions, and higher resistance to toxicity than dispersed sludge (Lettinga, 1995). Anaerobic granular sludge is often obtained in upflow anaerobic sludge blanket (UASB) reactors and their derivatives (Lettinga, 1995).

A balanced combination of a hydraulic upflow and biogas surface loading is generally considered to be critical to establish the correct physical selection pressure to promote the formation of granules (granulation) in UASB systems and their derivatives (Hulshoff Pol, 1989; Hulshoff Pol et al., 1983; Wiegant and Lettinga, 1985). This is typically accomplished by increasing the loading rate during startup in a stepwise fashion, which results in a stepwise increase in biogas production rate and upward liquid velocity. Consequently, the turbulence is increased, light particles are washed out, and growth of new biomass occurs on the remaining particles, which leads to the formation of granules (Wiegant and de Man, 1986). These remaining particles (nuclei) can be aggregates of microorganisms.

Even though the process of granulation has been studied extensively, and many factors affecting the formation and stability of granular sludge have been identified, understanding granule formation and stability remains a major challenge (Lettinga, 1995). Most models of granulation are based on information obtained from mature granules (Macleod et al., 1990; Morgan et al., 1991a; Wiegant, 1987). Schmidt and Ahring (1996) presented a more general model, which suggests that granulation involves adhesion of cells to nuclei and multiplication of attached cells. However, it has not been experimentally verified how granulation starts, how granules grow into conglomerates, and which factors determine granule stability. In addition, changes in granular 
structure and variations in the abundance and spatial distribution of microbial populations in granules throughout the granulation process have not yet been evaluated extensively. Therefore, it is important to know which organisms are present in aggregates that serve as nuclei, so that the startup of anaerobic systems can be adjusted to enhance the growth of these key players to promote granulation. Thus, understanding granulation requires the identification, quantification, and localization of the microbial populations involved in the formation of nuclei and granules.

The presence of Methanosaeta spp. in granules has been reported numerous times and these aceticlastic methanogens frequently have been found in the center of mature granules (Alphenaar, 1994; Harmsen et al., 1996b; Morgan et al., 1991a). Based on such observations, it has been hypothesized that Methanosaeta spp. can serve as nuclei for granulation (Macleod et al., 1990; Morgan et al., 1991a; Wiegant, 1987; Wiegant and de Man, 1986). This hypothesis is supported by results of Morvai et al. (1991), who demonstrated that granulation proceeded faster if Methanosaeta were enriched at the very beginning of reactor startup, and by findings of Grotenhuis et al. (1992), who reported that Methanosaeta concilii cells are hydrophobic and nearly uncharged at a $\mathrm{pH}$ of 7 . These characteristics may cause $M$. concilii to grow in cotton-like flocs or fiber-like bundles (Angenent et al., 2004; Huser et al., 1982; Kamagata and Mikami, 1990), which may serve as nuclei and be a growth support for other microorganisms to eventually form granules. Further support for this hypothesis comes from the observation that $M$. concilii cells have a high density (Scherer, 1983), which may insure that Methanosaeta cells are retained as nuclei during the physical selection process in UASB reactors and other granular systems. Addition of a pure culture of $M$. concilii was found to enhance granulation of dispersed digester sludge, indicating that Methanosaeta spp. play an important role in granulation (Morgan et al., 1991b). Nevertheless, no direct evidence is available to support the hypothesis that Methanosaeta spp. serve as nuclei for granulation.

It has also been reported that granules do not form with only Methanosaeta spp. and that other microorganisms ("coating bacteria") are needed to immobilize in the Methanosaeta aggregates (Uemura and Harada, 1993, 1995). These "coating bacteria" may be other methanogens, acetogens, and fermenting bacteria.

Besides Methanosaeta nuclei, researchers have hypothesized that nuclei for granulation may consist of fermenting bacteria (Jhung and Choi, 1995; Mulder et al., 1989; Vanderhaegen et al., 1992), Methanosarcina spp. (Grotenhuis et al., 1987; Wu et al., 1996), and syntrophic consortia (El-Mamouni et al., 1997). Syntrophic propionate oxidizers have been observed frequently in anaerobic granules where they form microcolonies with hydrogenotrophic methanogens (often Methanobrevibacter-like organisms) (Fang et al., 1995; Grotenhuis et al., 1991; Harmsen et al., 1996b). El-Mamouni et al. (1997) showed that granulation proceeded faster when UASB reactors were inoculated with nuclei containing ethanol-degrading syntrophic consortia than with other nuclei containing Methanosaeta spp., Methanosarcina spp., or fermenters, and therefore hypothesized that syntrophic consortia can also serve as nuclei for granulation.

In the present study, we tested the hypotheses that Methanosaeta spp. and syntrophic consortia form nuclei by monitoring granulation directly from nucleation to the formation of mature granules. To do so, we monitored microbial population changes and granulation processes in two laboratory-scale UASB reactors seeded with nongranular sludge. One reactor (reactor G) was fed glucose and was operated with an effluent acetate concentration below $200 \mathrm{mg} / \mathrm{L}$ to promote the growth of Methanosaeta spp. and to evaluate if Methanosaeta aggregates can serve as nuclei for granulation. The second reactor (reactor GP) was fed a mixture of glucose and propionate to enhance the growth of propionate-oxidizing syntrophic consortia as nuclei, and thus to assess if this strategy would improve granulation.

\section{MATERIALS AND METHODS}

\section{Reactor Operation}

Two 4.9-L glass UASB reactors with an inner diameter of $7.5 \mathrm{~cm}$ and seven sampling ports spaced $10 \mathrm{~cm}$ apart over the length of the reactor were operated at $35^{\circ} \mathrm{C}$ (Zheng, 1999). Both reactors were inoculated with non-granular sludge from a primary anaerobic sewage sludge digester at the Northeast wastewater treatment plant of the Urbana-Champaign Sanitary District (Urbana, IL). The inoculum was sieved through a $100-\mu \mathrm{m}$ sieve in order to remove large size particles or cell aggregates, which could potentially serve as nuclei for granulation. The initial volatile suspended solids (VSS) and suspended solids (SS) concentrations in both reactors were 6.64 and $10.48 \mathrm{~g} / \mathrm{L}$, respectively. The feed for reactor $\mathrm{G}$ consisted of $3,750 \mathrm{mg} / \mathrm{L}$ glucose (equivalent to $4,000 \mathrm{mg} / \mathrm{L}$ chemical oxygen demand [COD]), $277.7 \mathrm{mg} / \mathrm{L} \mathrm{NH} \mathrm{NH}_{4} \mathrm{Cl}$, $74.8 \mathrm{mg} / \mathrm{L} \quad \mathrm{KH}_{2} \mathrm{PO}_{4}, 25.5 \mathrm{mg} / \mathrm{L}\left(\mathrm{NH}_{4}\right)_{2} \mathrm{SO}_{4}, 110 \mathrm{mg} / \mathrm{L}$ $\mathrm{CaCl}_{2} \cdot 2 \mathrm{H}_{2} \mathrm{O}, 100 \mathrm{mg} / \mathrm{L} \mathrm{MgCl}_{2} \cdot 6 \mathrm{H}_{2} \mathrm{O}, 100 \mathrm{mg} / \mathrm{L}$ yeast extract, $3,000 \mathrm{mg} / \mathrm{L} \mathrm{NaHCO}_{3}$ as $\mathrm{CaCO}_{3}$ (the concentration of $\mathrm{NaHCO}_{3}$ was adjusted when necessary to maintain stable operation), $1 \mathrm{~mL}$ trace elements solution, and $1 \mathrm{~mL}$ vitamin solution dissolved in distilled deionized water $\left(\mathrm{dd} \mathrm{H}_{2} \mathrm{O}\right)$. The trace elements solution consisted of (concentrations are given in parentheses in $\mathrm{g} / \mathrm{L}): \mathrm{FeCl}_{2} \cdot 4 \mathrm{H}_{2} \mathrm{O}(2), \mathrm{H}_{3} \mathrm{BO}_{3}(0.05)$, $\mathrm{ZnCl}_{2} \quad(0.05), \quad \mathrm{CuCl}_{2} \quad(0.03), \mathrm{MnCl}_{2} \cdot 4 \mathrm{H}_{2} \mathrm{O} \quad(0.5)$, $\left(\mathrm{NH}_{4}\right)_{6} \mathrm{Mo}_{7} \mathrm{O}_{24} \cdot 4 \mathrm{H}_{2} \mathrm{O}(0.05), \mathrm{AlCl}_{3}(0.05), \mathrm{CoCl}_{2} \cdot 6 \mathrm{H}_{2} \mathrm{O}$ (0.05), $\mathrm{NiCl}_{2}(0.05)$, EDTA (0.5), $\mathrm{Na}_{2} \mathrm{SeO}_{3}(0.1)$, and $1 \mathrm{~mL}$ $36 \% \mathrm{HCl}$ (Zehnder et al., 1980). The vitamin solution contained (concentrations are given in parentheses in $\mathrm{mg} / \mathrm{L}$ ): biotin (2), folic acid (2), pyridoxin- $\mathrm{HCl}$ (10), riboflavin (5), thiamine (5), nicotinic acid (5), pantothenic acid (5), vitamin $\mathrm{B}_{12}$ (5), p-aminobenzoic acid (5), thioctic acid (5) (Wolin et al., 1963). The feed for reactor GP was the same as the feed for reactor $\mathrm{G}$ except that $40 \%$ of the COD from glucose was replaced by propionic acid (i.e., 2,250 mg/L glucose and $1,060 \mathrm{mg} / \mathrm{L}$ propionic acid were used in stead of $3,750 \mathrm{mg} / \mathrm{L}$ 
of glucose). To inhibit microbial growth in the feed, the feed tanks and tubing were autoclaved. Initially, the feed was prepared as follows: all components were dissolved in a small amount of $\mathrm{dd} \mathrm{H}_{2} \mathrm{O}$ and filtered through $0.22-\mu \mathrm{m}$ filters into freshly collected dd $\mathrm{H}_{2} \mathrm{O}$. Starting on day 41 , concentrated feed (without $\mathrm{NaHCO}_{3}$ ) was prepared and acidified to $\mathrm{pH} 3.0$ with $10 \% \mathrm{HCl}$. The concentrated feed was diluted to final concentrations by mixing with dilution water $\left(\mathrm{dd} \mathrm{H}_{2} \mathrm{O}\right.$ with $\mathrm{NaHCO}_{3}$ ) before entering the reactors.

The initial food to microorganism (F:M) ratios were 0.068 $\mathrm{g} \mathrm{COD} / \mathrm{g} \mathrm{VSS} /$ day for reactor $\mathrm{G}$ and $0.054 \mathrm{~g} \mathrm{COD} / \mathrm{g} \mathrm{VSS} /$ day for reactor GP. The volumetric loading rates of the two reactors were increased in a stepwise fashion when COD removals were higher than $80 \%$ and the effluent acetate concentrations were below $200 \mathrm{mg} / \mathrm{L}$ (Lettinga, 1995). The recycle flow rates for the two reactors were 5-40 times the influent flow rates depending on the operation and performance of the reactors (changes in operational conditions are summarized in Table I).

\section{Chemical Analyses}

Biogas was collected initially in Tedlar bags (Cole-Parmer Instrument Company, Vernon Hills, IL) and the volume produced was measured daily using liquid displacement. After 29 days of operation, biogas production was measured daily using gas meters (meter type $=1 \mathrm{dm}^{3}$, Schlumberger Industries, Dordrecht, The Netherlands). Other analyses were performed twice per week. The $\mathrm{CH}_{4}$ content of the biogas was determined using a gas chromatograph with a chromasorb $\mathrm{P}$ column $\left(4^{\prime}\right.$ long $\times 1 / 8^{\prime \prime}$ diameter $)$ and a thermal conductivity detector (GOW-MAC Instrument Co., Bethlehem, PA). Soluble COD levels were determined using Hach digestion vials (Loveland, CO). Glucose concentrations were determined using a glucose oxidase assay (Procedure No. 510, Sigma, St. Louis, MO). The $\mathrm{pH}$ values were measured using a pH meter (Accumet ${ }^{\circledR}$ pH meter 910, Fisher Scientific, Pittsburgh, PA). Volatile fatty acids (VFA) levels were determined by high performance liquid chromatography using a method developed by Ehrlich et al. (1981). The bicarbonate alkalinity was measured by titration (Anderson and Yang, 1992). SS and VSS concentrations were determined according to standard methods (APHA, 1995). The average VSS concentrations in the reactors were estimated as follows. The VSS concentrations were measured at the top, middle, and bottom of the sludge blanket (sampling locations changed depending on the thickness of the sludge bed). By assuming that the VSS concentrations changed linearly between two sampling locations, the total VSS present in the reactors were calculated. To obtain the average VSS concentration in each reactor, these estimates of total VSS were divided by the total reactor volume.

\section{Biomass Sample Collection and Handling}

Biomass samples for membrane hybridization with smallsubunit (SSU) ribosomal RNA (rRNA)-targeted oligonu- cleotide probes were obtained from the sludge blanket of each reactor from three different sampling ports (top, middle, and bottom of the sludge blanket; sampling locations changed depending on the thickness of the sludge bed) once a week. Biomass in the effluent was collected occasionally. Specimen preparation and RNA extraction were performed according to Raskin et al. (1994a). Biomass samples for fluorescence in situ hybridization (FISH) with SSU rRNAtargeted oligonucleotide probes were collected from the bottom of the reactors at different times during the experiment. Biomass preparation was performed according to de los Reyes et al. (1997). About ten to 20 granules from each cell pellet were further processed by embedding and sectioning according to the method of Harmsen et al. (1996b). In summary, the fixed granules were first dehydrated with $70 \%(\mathrm{v} / \mathrm{v})$ ethanol in water at $4{ }^{\circ} \mathrm{C}$ for about $16 \mathrm{~h}$. Subsequently, tertiary butanol was used to replace the ethanol and water in the granules. The granules were subsequently embedded in paraplast embedding medium (Sigma, St. Louis, MO) and the tertiary butanol was evaporated. The embedded granules were sectioned $(5-\mu \mathrm{m}$ slices $)$ by the Histological Laboratory of Diagnostic Medicine (College of Veterinary Medicine, University of Illinois at UrbanaChampaign). Sectioned ribbons were stretched in $50^{\circ} \mathrm{C}$ water and transferred to microscope slides (positively charged slides coated with saline). The slides were dried at $42^{\circ} \mathrm{C}$ for about $16 \mathrm{~h}$ and the paraplast embedding medium was removed as described previously (Harmsen et al., 1996b). Non-granular, fixed biomass samples were applied onto Teflon coated two-well $(20 \times 20 \mathrm{~mm})$ microscope slides (Cel-Line Associates, Inc., Newfield, NJ).

\section{Membrane Hybridization}

Membrane hybridizations were conducted using Magna Charge membranes (Micron Separation, Inc., Westborough, MA) as previously described (Griffin et al., 1998; Raskin et al., 1996), except that poly (A) was eliminated from the dilution water and that about $150 \mathrm{ng}$ total nucleic acid was applied to each slot (Alm et al., 2000). The oligonucleotide probes used together with the corresponding reference RNAs are listed in Table II. Probes were $5^{\prime}$ end labeled with $\left[\gamma^{32} \mathrm{P}\right]$ ATP (Raskin et al., 1994b). Membranes were hybridized and washed at the wash temperature $\left(T_{\mathrm{w}}\right)$ previously determined for each probe (Table II). The hybridization signal was quantified using a PhosphorImager (Molecular Dynamics, Sunnyvale, CA) and the abundance of each phylogenetic target group was expressed as a percentage of the total SSU rRNA as determined using a universal probe, S-*-Univ-1390a-A-18 (Raskin et al., 1997; Zheng et al., 1996).

\section{FISH and Size Measurement of Aggregates}

Slides with specimens were air-dried and dehydrated by passing through 50\%, 80\%, and $96 \%$ ethanol for 3 min each. Probes used for FISH are listed in Table II. FISH was conducted at $46^{\circ} \mathrm{C}$ with a hybridization buffer without 


\begin{tabular}{|c|c|c|c|c|c|}
\hline & \multirow[b]{2}{*}{ Day } & \multirow[b]{2}{*}{ Change in operating condition (Fig. 1a and b) } & \multicolumn{2}{|c|}{ Reactor } & \multirow[b]{2}{*}{ Effect on reactor performance (Fig. 1c-h) } \\
\hline & & & $\mathrm{G}$ & GP & \\
\hline Period 1 & $1-22$ & $\begin{array}{l}\mathrm{RR}=10 \mathrm{~mL} / \mathrm{min}, \mathrm{HRT} \text { decreased from } 11 \text { to } 5 \text { day. } \\
\quad \mathrm{UFV}=3.4 \mathrm{~m} / \text { day }\end{array}$ & $\checkmark$ & $\checkmark$ & $\begin{array}{l}\text { Initial washout and adaptation of biomass to } \\
\text { substrates }\end{array}$ \\
\hline \multirow[t]{2}{*}{ Days 1-48 initial washout } & 23 & $\begin{array}{l}\text { Increase in RR to } 17 \mathrm{~mL} / \mathrm{min} \text { and VLR to } 1.0 \mathrm{~g} \mathrm{COD} / \\
\mathrm{L} / \text { day. } \mathrm{HRT}=3.4 \text { day and } \mathrm{UFV}=5.9 \mathrm{~m} / \text { day }\end{array}$ & $\checkmark$ & $\checkmark$ & $\begin{array}{l}\text { Increase in effluent VSS, decrease in reactor } \\
\text { VSS. Effluent COD remained low }\end{array}$ \\
\hline & 35 & $\begin{array}{l}\text { Increase in VLR to } 2 \mathrm{~g} \mathrm{COD} / \mathrm{L} / \text { day. } \mathrm{HRT}=2.1 \text { day } \\
\text { and } \mathrm{UFV}=6.1 \mathrm{~m} / \text { day }\end{array}$ & $\checkmark$ & $\checkmark$ & $\begin{array}{l}\text { Increase in effluent VSS, decrease in reactor } \\
\text { VSS. Effluent COD remained low }\end{array}$ \\
\hline Period 2 & 49 & $\begin{array}{l}\text { Increase in VLR to } 2.2 \mathrm{~g} \mathrm{COD} / \mathrm{L} / \text { day. } \mathrm{HRT}=1.8 \text { day } \\
\text { and } \mathrm{UFV}=6.1 \mathrm{~m} / \text { day }\end{array}$ & $\checkmark$ & $\checkmark$ & $\begin{array}{l}\text { Rapid increase in reactor VSS. Effluent COD } \\
\text { remained low }\end{array}$ \\
\hline \multirow[t]{4}{*}{$\begin{array}{l}\text { Days } 49-118 \\
\quad \text { proliferation of } \\
\text { fermenters }\end{array}$} & 63 & $\begin{array}{l}\text { Increase in VLR to } 3.5 \mathrm{~g} \mathrm{COD} / \mathrm{L} / \text { day. } \mathrm{HRT}=1.2 \\
\quad \text { day, and } \mathrm{UFV}=6.5 \mathrm{~m} / \text { day }\end{array}$ & $\checkmark$ & $\checkmark$ & $\begin{array}{l}\text { Increase in effluent VSS, decrease in reactor } \\
\text { VSS. Effluent COD, acetate, propionate } \\
\text { exceeded } 200,50,50 \mathrm{mg} / \mathrm{L} \text {, respectively }\end{array}$ \\
\hline & 84 & F:M ratio reached $3.6 \mathrm{~g} \mathrm{COD/g} \mathrm{VSS/day}$ & $\checkmark$ & & $\begin{array}{l}\text { Unstable conditions. Effluent COD, acetate } \\
\text { propionate exceeded } 500,150,100 \mathrm{mg} / \mathrm{L}\end{array}$ \\
\hline & 86 & $\begin{array}{l}\text { Decrease in VLR to } 2.8 \mathrm{~g} \mathrm{COD} / \mathrm{L} / \text { day. } \mathrm{HRT}=1.4 \\
\quad \text { day, and } \mathrm{UFV}=6.3 \mathrm{~m} / \text { day }\end{array}$ & $\checkmark$ & & $\begin{array}{l}\text { Initial increase in effluent VSS, subsequen } \\
\text { increase in reactor VSS. Effluent COD } \\
\text { acetate, propionate decreased to } 150,50,50 \\
\mathrm{mg} / \mathrm{L}\end{array}$ \\
\hline & 100 & $\begin{array}{l}\text { Increase in VLR to } 3.3 \mathrm{~g} \mathrm{COD} / \mathrm{L} / \text { day. } \mathrm{HRT}=1.2 \\
\quad \text { day, and } \mathrm{UFV}=6.5 \mathrm{~m} / \text { day }\end{array}$ & $\sqrt{ }$ & & $\begin{array}{l}\text { Increase in effluent VSS, decrease in reactor } \\
\text { VSS. Effluent COD initially increased; then } \\
\text { decreased to } 150 \mathrm{mg} / \mathrm{L}\end{array}$ \\
\hline Period 3 & 119 & $\begin{array}{l}\text { Increase in RR to } 33 \mathrm{~mL} / \mathrm{min} \text { and VLR to } 4.5 \mathrm{~g} \mathrm{COD} / \\
\mathrm{L} / \text { day. } \mathrm{HRT}=0.9 \text { day, and } \mathrm{UFV}=11.9 \mathrm{~m} / \text { day }\end{array}$ & $\checkmark$ & $\checkmark$ & $\begin{array}{l}\text { Increase in effluent VSS, decrease in reactor } \\
\text { VSS. Effluent COD increased slightly to } \\
\text { approximately } 200 \mathrm{mg} / \mathrm{L}\end{array}$ \\
\hline \multirow[t]{6}{*}{$\begin{array}{l}\text { Days 119-224 washout of } \\
\text { fermenters }\end{array}$} & $110-125$ & F:M ratio maintained high & $\checkmark$ & $\checkmark$ & $\begin{array}{l}\text { High levels of effluent VSS due to excessive } \\
\text { growth of fermenters. Effluent COD and } \\
\text { VFA levels increased sharply }\end{array}$ \\
\hline & 137 & $\begin{array}{c}\text { Decrease of VLR to } 3.9 \mathrm{~g} \mathrm{COD} / \mathrm{L} / \text { day (power } \\
\text { problem). } \mathrm{HRT}=1.0 \text { day, } \mathrm{UFV}=11.8 \mathrm{~m} / \text { day }\end{array}$ & $\checkmark$ & $\checkmark$ & $\begin{array}{l}\text { Increase in reactor VSS. Effluent COD levels } \\
\text { decreased }\end{array}$ \\
\hline & 152 & $\begin{array}{l}\text { Increase in RR to } 41.7 \mathrm{~mL} / \mathrm{min} \text { and VLR to } 5.0 \mathrm{~g} \\
\mathrm{COD} / \mathrm{L} / \text { day. } \mathrm{HRT}=0.8 \mathrm{day}, \mathrm{UFV}=15.0 \mathrm{~m} / \mathrm{day}\end{array}$ & $\checkmark$ & $\checkmark$ & $\begin{array}{l}\text { Increase in reactor VSS }(\mathrm{G}) \text {, decrease in reactor } \\
\text { VSS (GP). Increase in effluent COD } \\
\text { acetate and propionate (reactor GP) }\end{array}$ \\
\hline & 168 & $\begin{array}{l}\text { Large increase in RR to } 87 \mathrm{~mL} / \mathrm{min}, \mathrm{UFV}=29.7 \mathrm{~m} / \\
\text { day }\end{array}$ & $\checkmark$ & $\checkmark$ & $\begin{array}{l}\text { Increase in effluent VSS (GP), decrease in } \\
\text { reactor VSS. Effluent COD remained con- } \\
\text { stant }\end{array}$ \\
\hline & 182 & $\begin{array}{l}\text { Increase in VLR to } 6.2 \mathrm{~g} \mathrm{COD} / \mathrm{L} / \text { day, } \mathrm{HRT}=0.6 \\
\quad \text { day, } \mathrm{UFV}=30.0 \mathrm{~m} / \mathrm{day}\end{array}$ & $\checkmark$ & $\sqrt{ }$ & $\begin{array}{l}\text { Decrease in reactor VSS. Effluent COD } \\
\text { increased to } 500 \mathrm{mg} / \mathrm{L}(\mathrm{G}) \text { and } 750 \mathrm{mg} / \mathrm{L} \\
\text { (GP) }\end{array}$ \\
\hline & 201 & Increase in RR to $122 \mathrm{~mL} / \mathrm{min}, \mathrm{UFV}=41.3 \mathrm{~m} /$ day & $\checkmark$ & & $\begin{array}{l}\text { Increase in effluent VSS, decrease in reactor } \\
\text { VSS. Effluent COD remained constant }\end{array}$ \\
\hline
\end{tabular}

RR, recycle rate; VLR, volumetric loading rate; UFV, upflow velocity; HRT, hydraulic retention time.

formamide and washes were performed at $48^{\circ} \mathrm{C}$ with a wash buffer without formamide (Amann et al., 1992). After hybridization, the slides were stained with $4^{\prime}, 6$-diamidino2-phenylindole (DAPI, Sigma, St. Louis, MO) $(6.26 \mu \mathrm{g} / \mathrm{mL}$ in $0.1 \mathrm{M}$ Tris- $\mathrm{HCl}$, and $0.9 \mathrm{M} \mathrm{NaCl}, \mathrm{pH} 7.2$ ) and rinsed with dd $\mathrm{H}_{2} \mathrm{O}$. For size measurement of aggregates, the hybridization step was omitted and only DAPI staining was performed. Fluorescent images were captured using a liquid-cooled charge coupled device (CCD) camera (Photometrics Ltd., Tuscon, AZ) mounted onto an epifluorescence microscope (Axioskop, Carl Zeiss, Germany). IPLab Spectrum (Signal Analytics, Vienna, VA) and Adobe Photoshop 3.0 (Adobe, Seattle, WA) were used for image editing and printing of FISH images. Areas of aggregates were measured with IPLab Spectrum. About 500 aggregates (with areas between 500 and $620,000 \mu \mathrm{m}^{2}$ ) were measured for each sample. The cumulative size distribution of the measured areas was calculated using the histogram data analysis tool in Excel 6.0 (Microsoft, Seattle, WA).

\section{RESULTS}

\section{Reactor Operating Conditions and General Performance Results}

Reactor operating conditions were changed throughout the operating period to promote granulation (e.g., increases in volumetric loading rates and recycling rates). These changes and their effects on reactor performance and biomass levels are summarized in Table I. Reactor performance results are 
Table II. SSU rRNA-targeted oligonucleotide probes, target groups, wash temperatures $\left(T_{\mathrm{w}}\right)$, and reference RNAs when used in membrane hybridization.

\begin{tabular}{|c|c|c|c|c|}
\hline Probe & Target group & $T_{\mathrm{w}}\left({ }^{\circ} \mathrm{C}\right)^{\mathrm{a}}$ & Reference RNA & Reference \\
\hline S-*-Univ-1390-a-A-18 & Most organisms & 44 & NA & $\mathrm{i}$ \\
\hline S-D-Bact-0338-a-A-18 ${ }^{\mathrm{a}}$ & Most Bacteria & $\mathrm{NA}^{\mathrm{b}}$ & NA & ii \\
\hline S-D-Arch-0915-a-A-20a & Most Archaea & NA & NA & ii \\
\hline S-O-Msar-0860-a-A-21 & Methanosarcinales & 60 & Methanosarcina acetivorans & iv \\
\hline S-O-Mmic-1200-a-A-21 & Methanomicrobiales & 53 & Methanogenium cariaci & iv \\
\hline S-F-Mcoc-1109-a-A-20 & Methanococcaceae & 55 & Methanococcus voltae & iv \\
\hline S-F-Mbac-0310-a-A-22 & Methanobacteriaceae & 57 & Methanobrevibacter arboriphilicus & iv \\
\hline S-G-Msar-0821-a-A-21 & Methanosarcina spp. & 60 & Methanosarcina acetivorans & iv \\
\hline S-G-Mbvb-0406-a-A-22 & Methanobrevibacter spp. & 51 & Methanobrevibacter arboriphilicus & $\mathrm{v}$ \\
\hline S-S-M.con-0381-a-A-22 ${ }^{\mathrm{a}}$ & Methanosaeta concilii & 57 & Methanogenium cariaci & vi \\
\hline S-*-Synb-0838-a-A-21 & Syntrophobacter spp. & 55 & Syntrophobacter fumaroxidans & $\mathrm{v}$ \\
\hline S-G-Dsbb-0660-a-A-20 & Desulfobulbus spp. & 57 & Desulfobulbus propionicus ${ }^{\mathrm{c}}$ & vii \\
\hline
\end{tabular}

${ }^{\text {a }}$ Probes used for FISH, S-D-Bact-0338-a-A-18 was labeled with indocarbocyanine 3 (Cy3) S-D-Arch-0915-a-A-20 was labeled with Oregon Green, and S-S-M.con-0381-a-A-22 was labeled with indocarbocyanine 5 (Cy5) (Operon Technology, Inc., Alameda, CA).

${ }^{b} \mathrm{NA}$, not applicable

${ }^{\mathrm{c}}$ In-vitro transcribed rRNA McMahon et al. (1998).

${ }^{d}$ References: i, Zheng et al. (1996); ii, Amann et al. (1990); iii, Stahl and Amann (1991); iv, Raskin et al. (1994b); v, Zheng (1999); vi, Zheng and Raskin (2000); and vii, (Devereux et al. (1992).

presented in Figure 1. The volumetric loading rates for both reactors were initially $0.45 \mathrm{~g} \mathrm{COD} / \mathrm{L} /$ day and were increased in a stepwise fashion to approximately $6 \mathrm{~g} \mathrm{COD} / \mathrm{L} /$ day (Fig. 1a and b), while the bicarbonate alkalinity in the effluent of both reactors was maintained between 1,000 and $3,000 \mathrm{mg} / \mathrm{L}$ as $\mathrm{CaCO}_{3}$. For reactor $\mathrm{G}$, the effluent $\mathrm{pH}$ ranged from 6.5 to 8.5 with an average of 7.1 (standard error $[\mathrm{SE}]=0.5$ ), while the effluent $\mathrm{pH}$ for reactor GP varied between 6.5 and 8.4 with an average of $7.2(\mathrm{SE}=0.5)$. The effluent soluble COD concentrations remained below 600 and $800 \mathrm{mg} / \mathrm{L}$ for reactor $\mathrm{G}$ and GP, respectively, resulting in soluble COD removal efficiencies of at least $67.4 \%$ and $69.9 \%$, respectively. Glucose concentrations in the effluent and in samples taken from ports at different heights of the reactors were always below the detection limit of $0.5 \mathrm{mg} / \mathrm{L}$. Acetate and propionate concentrations in the effluent are given in Figure 1e and $\mathrm{f}$ for reactor G and GP, respectively. Except for the final period of operation for reactor $\mathrm{G}$, the acetate levels were maintained below $200 \mathrm{mg} / \mathrm{L}$ to support the growth of M. concilii. The average methane content of the biogas in reactor GP was higher than the one for reactor $G(58.3 \pm 7.4$ and $50.8 \pm 6.5 \%$, respectively), while the biogas production was lower for reactor GP compared to reactor G, because propionate is a more reduced substrate compared to glucose.

\section{Microbial Population Dynamics, Change in Size of Aggregates, and Structural Changes During Granulation}

Three different operating periods can be distinguished: period 1 (days 1-48), initial biomass washout and start of nucleation; period 2 (days 49-118), proliferation of fermenters; period 3 (days 119-224), increase of recycling rate to wash out fermenters. Inoculum characteristics, changes in biomass levels, microbial population dynamics, changes in aggregate size, and structural changes during granulation were determined during these periods and the results are presented in Figures $1 \mathrm{~g}, \mathrm{~h}$ and $2-5$ and are discussed below.

\section{Inoculum}

Using FISH and DAPI staining, it was observed that the anaerobic sludge inoculum contained free-living cells and small aggregates. Aggregate size measurements indicated that more than $94 \%$ of the cell aggregates had areas of less than $5,000 \mu \mathrm{m}^{2}$ (day 0 in Fig. 2). Membrane hybridization results indicated that this inoculum contained primarily methanogens of the orders Methanosarcinales and Methanomicrobiales (day 0 in Fig. 3). The order of Methanosarcinales, which contains all known aceticlastic methanogens and consists of the families Methanosarcinaceae and Methanosaetaceae (Boone et al., 1993), accounted for 6\% of the total SSU rRNA. M. concilii was the predominant representative of this order, whereas Methanosarcina spp. levels were low. The order of Methanomicrobiales, which consists of the families Methanomicrobiaceae, Methanocorpusculaceae, and Methanospirillaceae (Boone et al., 1993), which are primarily hydrogenotrophic methanogens, accounted for $6.5 \%$ of the total SSU rRNA. The level of Methanococcaceae, most of which are slightly halophilic hydrogenotrophic methanogens, was below $0.2 \%$ in the inoculum and remained this low for the entire experiment (data not shown). Hydrogen-utilizing methanogens of the family Methanobacteriaceae were present at $0.4 \%$ of the total SSU rRNA in the inoculum (Fig. 3c and d). The SSU rRNA levels of Syntrophobacter and Desulfobulbus spp., two genera that contain propionate-degrading species, were $0.3 \%$ and $1.9 \%$, respectively.

\section{Period 1 (Days 1-48)}

During period 1, the methanogen population dynamics for reactors G and GP were similar. Levels of $M$. concilii SSU rRNA gradually increased to $22.5 \%$ in reactor $\mathrm{G}$ and to $21.1 \%$ 
a

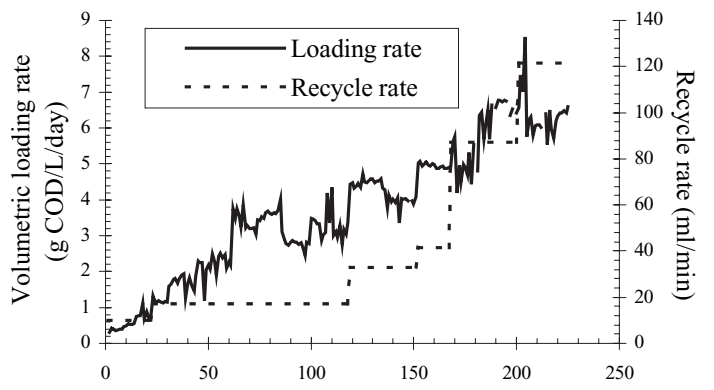

c

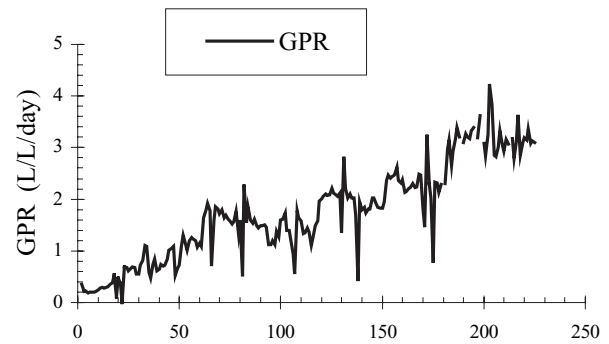

$\mathbf{e}$

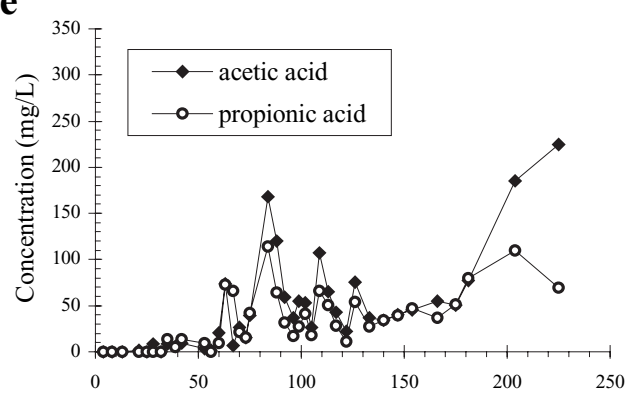

g

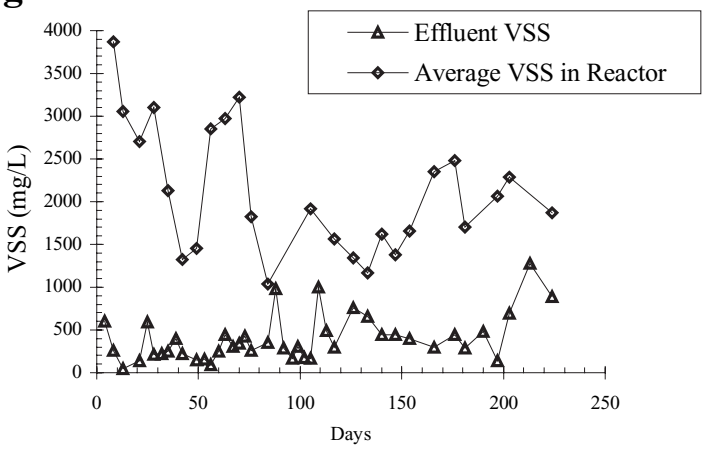

b

Reactor GP

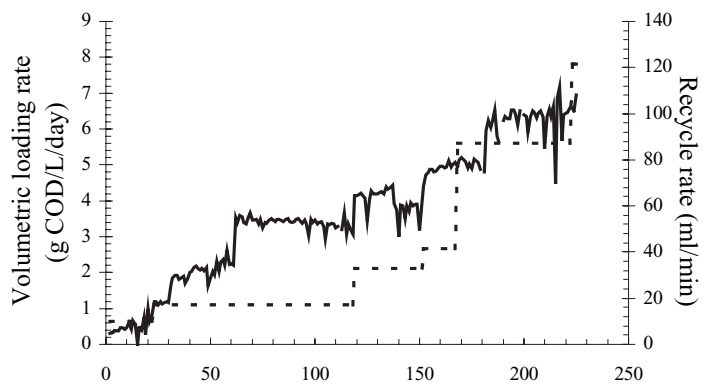

d

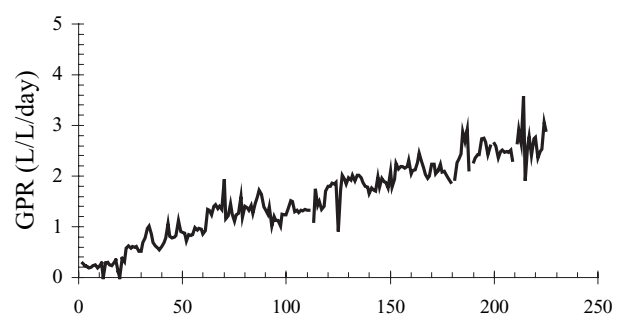

f

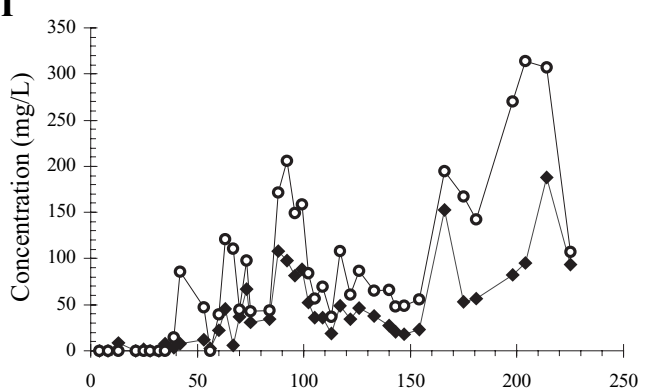

h

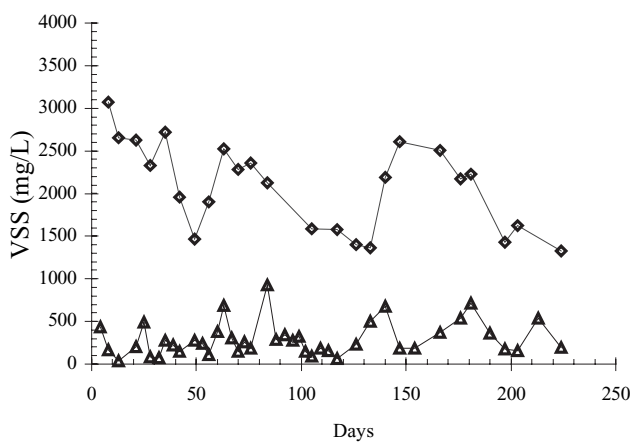

Figure 1. Performance data for reactors $\mathrm{G}$ and $\mathrm{GP}$ : volumetric loading rate and recycle rate for reactor $\mathrm{G}(\mathbf{a})$ and reactor GP (b); gas production rate (GPR) for reactor $\mathrm{G}(\mathbf{c})$ and reactor $\mathrm{GP}(\mathbf{d})$; acetic and propionic acid concentrations in reactor $\mathrm{G}(\mathbf{e})$ and reactor $\mathrm{GP}(\mathbf{f})$ : volatile suspended solids in the effluent and mixed liquor for reactor $\mathrm{G}(\mathbf{g})$ and reactor $\mathrm{GP}(\mathbf{h})$.

in reactor GP (Fig. 3a and b). This increase was accompanied by a decrease of the total biomass levels in the two reactors (Fig. $1 \mathrm{~g}$ and $\mathrm{h}$ ). On day 35, after significant biomass washout, only a few free cells and small aggregates containing $M$. concilii were observed by epifluorescence microscopy and FISH (Fig. 5a and b). On day 49, the aggregates had a similar structure but were bigger (data not shown). SSU rRNA levels of Methanomicrobiales remained relatively constant during period 1 in reactors $\mathrm{G}$ and GP, while the total biomass was decreasing. The levels of Methanobacteriaceae remained very low during this period (Fig. 3c and d). Methanobrevibacter spp., which belongs to the family Methanobacteriaceae, only increased slightly from $0.4 \%$ to $0.5 \%$ and to $0.7 \%$ in reactors $\mathrm{G}$ and GP, respectively.

Syntrophobacter spp. SSU rRNA levels remained below $1 \%$ during period 1 in reactor $\mathrm{G}$, while their levels increased from $0.3 \%$ to $2.1 \%$ in reactor GP (Fig. 3e and f). This observation is consistent with the presence of propionate in 
a

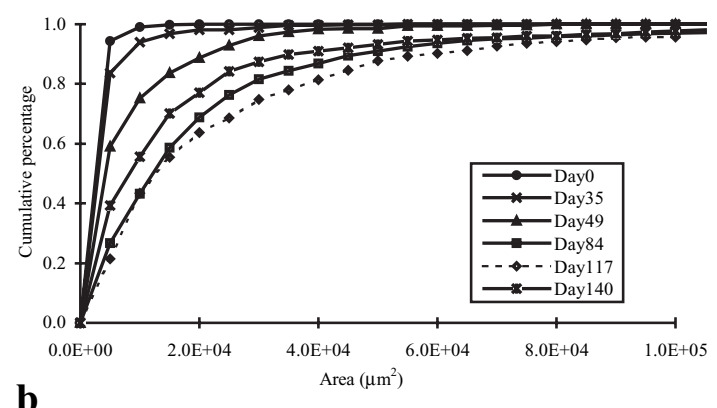

b

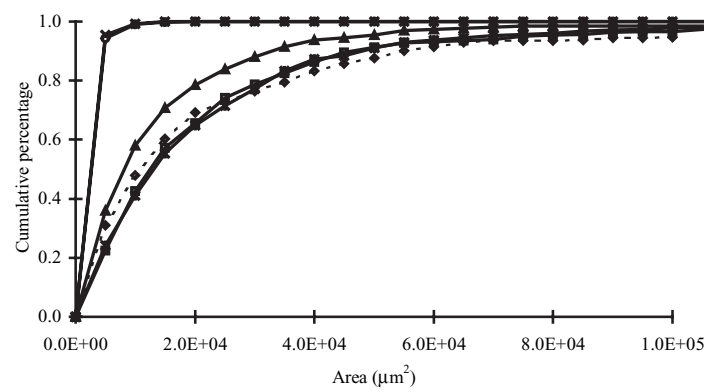

c

\begin{tabular}{ccccccc}
\multicolumn{2}{c}{ Average cell aggregates diameter $(\mu \mathrm{m})$} & & & & \\
& Day 0 & Day 35 & Day 49 & Day 84 & Day 117 & Day 140 \\
Reactor G & 49 & 66 & 99 & 162 & 183 & 143 \\
Reactor GP & 49 & 46 & 134 & 166 & 185 & 165
\end{tabular}

Figure 2. Size distribution of small aggregates in reactor $\mathrm{G}(\mathbf{a})$ and reactor GP (b). The measured areas were between 500 and $620,000 \mu \mathrm{m}^{2}$. Average cell aggregates diameter $(\mu \mathrm{m})$ calculated based on the average size (area) of the cell aggregates and assuming the aggregates were spheres (c).

the influent of reactor GP only. Desulfobulbus spp. remained at approximately $2 \%$ of the total SSU rRNA in both systems for period 1 . Since only $0.75 \mathrm{mg} / \mathrm{L}(7.8 \mu \mathrm{M})$ of sulfate was present in the influent, and since Desulfobulbus spp. SSU rRNA levels were considerable in both reactors, it is likely that these sulfate-reducing bacteria were supported by degrading propionate syntrophically.

The results presented in Figure 4a and c indicate that on days 8 and 28, the sludge blankets in both reactors exhibited uniform distributions of methanogen levels. However, toward the end of period 1 (day 42), the sludge blanket became stratified with higher levels of Methanosarcinales at the bottom of the blanket. The effluent biomass from both reactors contained lower levels of Methanosarcinales compared to the biomass in the reactors, indicating that $M$. concilii, the predominant member of the Methanosarcinales, exhibited excellent settling characteristics and was retained in the system. Except for reactor G on day 42, the levels of Methanomicrobiales were similar in the effluent biomass compared to the biomass inside the reactors, demonstrating that their settling ability was similar to the settling ability of the surrounding biomass. On day 8 for both reactors and on day 42 for reactor G, Syntrophobacter spp. levels were lower in the effluents than inside the reactors (Fig. 4b and d).

Size measurements of cell aggregates were taken on days 35 and 49 during period 1 (Fig. 2). For reactor G, the sizes of cell aggregates increased slightly between days 0 and 35 , and more substantially between days 35 and 49 . For reactor GP, there were almost no changes in aggregates sizes from days 0 to 35 , but there was a substantial increase between days 35 and 49. The cell aggregates in reactor GP were larger than in reactor $\mathrm{G}$ on day 49: for example, 59\% of the cell aggregates were less than $5,000 \mu \mathrm{m}^{2}$ and $93 \%$ of them were less than $25,000 \mu \mathrm{m}^{2}$, in reactor $\mathrm{G}$, and $36 \%$ of the cell aggregates were less than $5,000 \mu \mathrm{m}^{2}$ and $84 \%$ of them were less than $25,000 \mu \mathrm{m}^{2}$, in reactor GP.

\section{Period 2 (Days 49-118)}

At the beginning of period 2 (days 49-62), the total biomass levels in reactors $\mathrm{G}$ and GP rapidly increased from approximately $1,500 \mathrm{mg} / \mathrm{L}$ to over $3,000 \mathrm{mg} / \mathrm{L}$ and $2,500 \mathrm{mg} / \mathrm{L}$, respectively (Fig. $1 \mathrm{~g}$ and $\mathrm{h}$ ). Therefore, in order to maintain reasonable F:M ratios, the volumetric loading rates in both reactors were increased from around $2.2 \mathrm{~g} \mathrm{COD} / \mathrm{L} /$ day to about $3.5 \mathrm{~g} \mathrm{COD/L/day} \mathrm{on} \mathrm{day} 63$ (Fig. 1a and b). After this change, the biomass levels in both reactors decreased (Fig. $1 \mathrm{~g}$ and $\mathrm{h}$ ), and the decrease was more drastic in reactor $\mathrm{G}$. Membrane hybridization results indicate that relative SSU rRNA levels of methanogens and acetogens decreased from days 49 to 84, except for Methanobacteriaceae, which increased during this period to $2.4 \%$ in reactor $\mathrm{G}$ and to $1.5 \%$ in reactor GP (Fig. 3c and d). For example, the levels of $M$. concilii decreased to $4.8 \%$ and $8.3 \%$ in reactors G and GP, respectively (Fig. 3a and b), and the levels of Methanomicrobiales decreased to approximately $2 \%$ and $6 \%$ in reactors $\mathrm{G}$ and GP, respectively (Fig. 3c and d). The decrease in relative abundance of methanogens and acetogens was due to the rapid growth of fermenting bacteria. The stratified sludge blanket observed for day 42 (with respect to Methanosarcinales) was also lost during this period (Fig. 4a and c), apparently due to the rapid growth of fermenting bacteria and the loss of biomass from the systems, which reduced the blanket height considerably.

During this period (days 49-84), the aggregate sizes in both reactors continued to increase substantially (Fig. 2), which was due to the growth of filamentous bacteria on the surface of the granules. Visible granules, with a diameter of approximately $1.5 \mathrm{~mm}$, were first observed in both reactors around day 75. Indeed, large amounts of filamentous bacterial cells were present on the surface of the aggregates (Fig. $5 \mathrm{c}$ and d). Besides attaching to aggregates that were initiated by $M$. concilii ( $M$. concilii aggregates), aggregates solely consisting of filamentous bacteria were also seen with epifluorescence microscopy (data not shown). Filamentous bacteria gave the aggregates a whitish appearance. Through centrifugation of a mixture of aggregates, it was determined that the whitish aggregates had lower settling characteristics than the darker M. concilii aggregates. Whitish aggregates were present in the effluent and were washed out from the reactors. Even though $M$. concilii aggregates had a higher settling ability than the whitish aggregates, M. concilii aggregates with substantial amounts of filamentous bacteria attached also were washed out. This phenomenon is known as 
a

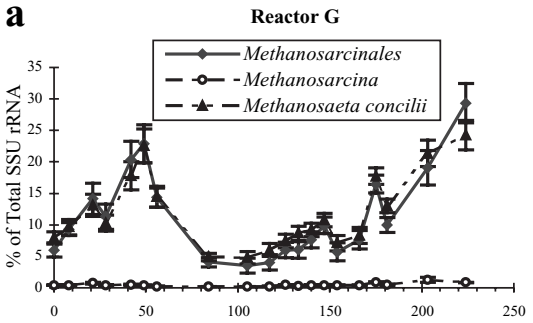

c

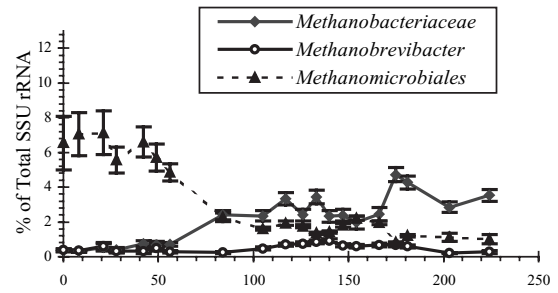

e

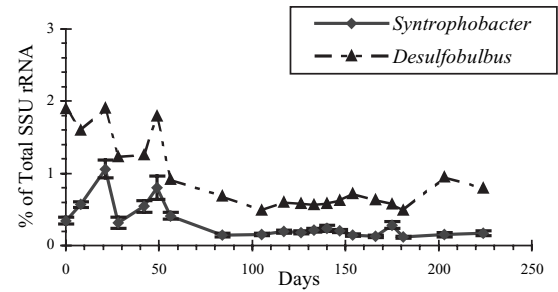

$\mathbf{b}$

Reactor GP

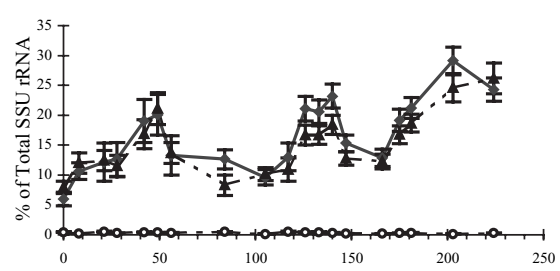

d
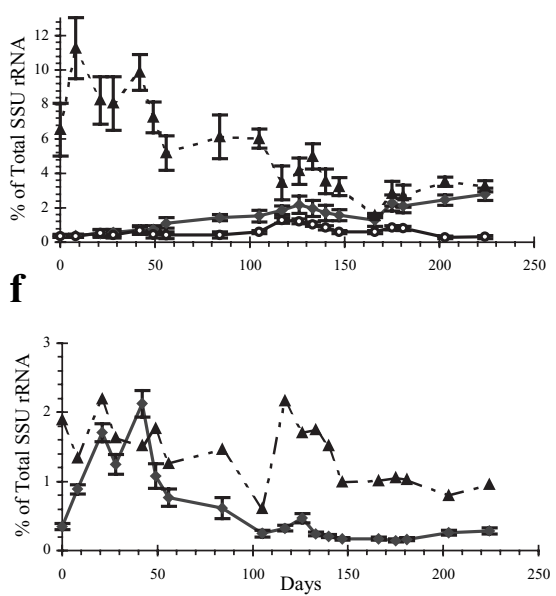

Figure 3. Microbial population dynamics in the bottom of the sludge beds of reactors G (a, c, e) and GP (b, d, f); aceticlastic methanogens (a and b); hydrogenotrophic methanogens (c and d); and Syntrophobacter and Desulfobulbus (e and f). Population SSU rRNA levels are expressed as a percentage of the total SSU rRNA and error bars indicate standard deviations obtained by triplicate application of the same RNA extract to hybridization membranes.

bulking, which can cause massive biomass loss from UASB systems (Alphenaar, 1994). The effluent VSS increased considerably (up to $1,000 \mathrm{mg} / \mathrm{L}$ on day 84 ) during this period for both reactors (Fig. $1 \mathrm{~g}$ and $\mathrm{h}$ ).

Unstable conditions were observed (e.g., high levels of acetate and propionate, see Fig. 1e) in reactor $\mathrm{G}$ around day 84 due to washout of biomass caused by bulking (Fig. $1 \mathrm{~g}$ ). To prevent further problems, the volumetric loading rate was reduced for reactor $\mathrm{G}$ on day 86 . This change resulted in an increase in the biomass level in reactor $\mathrm{G}$ for a short period (days 87-100; Fig. 1g) and prevented complete reactor failure. The levels of methanogens in reactor $G$ remained relatively stable during this recovery period, as well as after a small increase in the volumetric loading rate on day 100 (Fig. 1a). After day 84, Methanobacteriaceae became the dominant hydrogenotrophic methanogens in reactor $\mathrm{G}$, but not in reactor GP (Fig. 3c and d). Between days 87 and 100, the levels of Syntrophobacter spp. continued to decrease, while Desulfobulbus spp. remained constant in reactor G (Fig. 3e).

The volumetric loading rate remained the same for reactor GP (Fig. 1b; between days 63 and 118). The biomass level in reactor GP continued to decrease (Fig. 1h). Elevated levels of acetate and propionate were observed in the effluent between days 88 and 102 (Fig. 1f). Desulfobulbus spp. levels on day 105 had dropped to $0.6 \%$, and then increased again to $2.2 \%$ on day 117 (Fig. 3f). Syntrophobacter spp. decreased substantially during period 2 (Fig. 3f), while Methanobac- teriaceae increased slowly (Fig. 3d). The level of Methanosarcinales remained stable during this period, while the level of Methanomicrobiales decreased to $3.5 \%$ on day 117 (Fig. 3b). The aggregate size increased slightly between days 84 and 117 as shown in Figure 2.

On day 105, granules were collected and analyzed for microbial composition. For both reactors, the levels of methanogens, Syntrophobacter, and Desulfobulbus were higher in the granules than in the total biomass (Fig. 4), which during this time consisted of a mixture of granules and dispersed sludge.

\section{Period 3 (Days 119-224)}

Recycling rates and volumetric loading rates for reactors $G$ and GP were increased on day 119 to washout fermenting bacteria and to stimulate granulation. The increase in recycle rates led to higher shear forces that were able to remove the layers of filamentous bacteria from the aggregates by day 140 (Fig. 5e and f). The increase in shear force, combined with a slight adjustment of the volumetric loading rate on day 137 , finally resulted in an increase in the biomass levels in the reactors due to improved settling characteristics of the aggregates. $M$. concilii levels started to increase slowly and an increases in $M$. concilii levels also were observed after the recycle rates were increased on day 168 in both reactors (Fig. 3a and b). On day 181, M. concilii was mostly observed in the center of the aggregates in both reactors (data not 

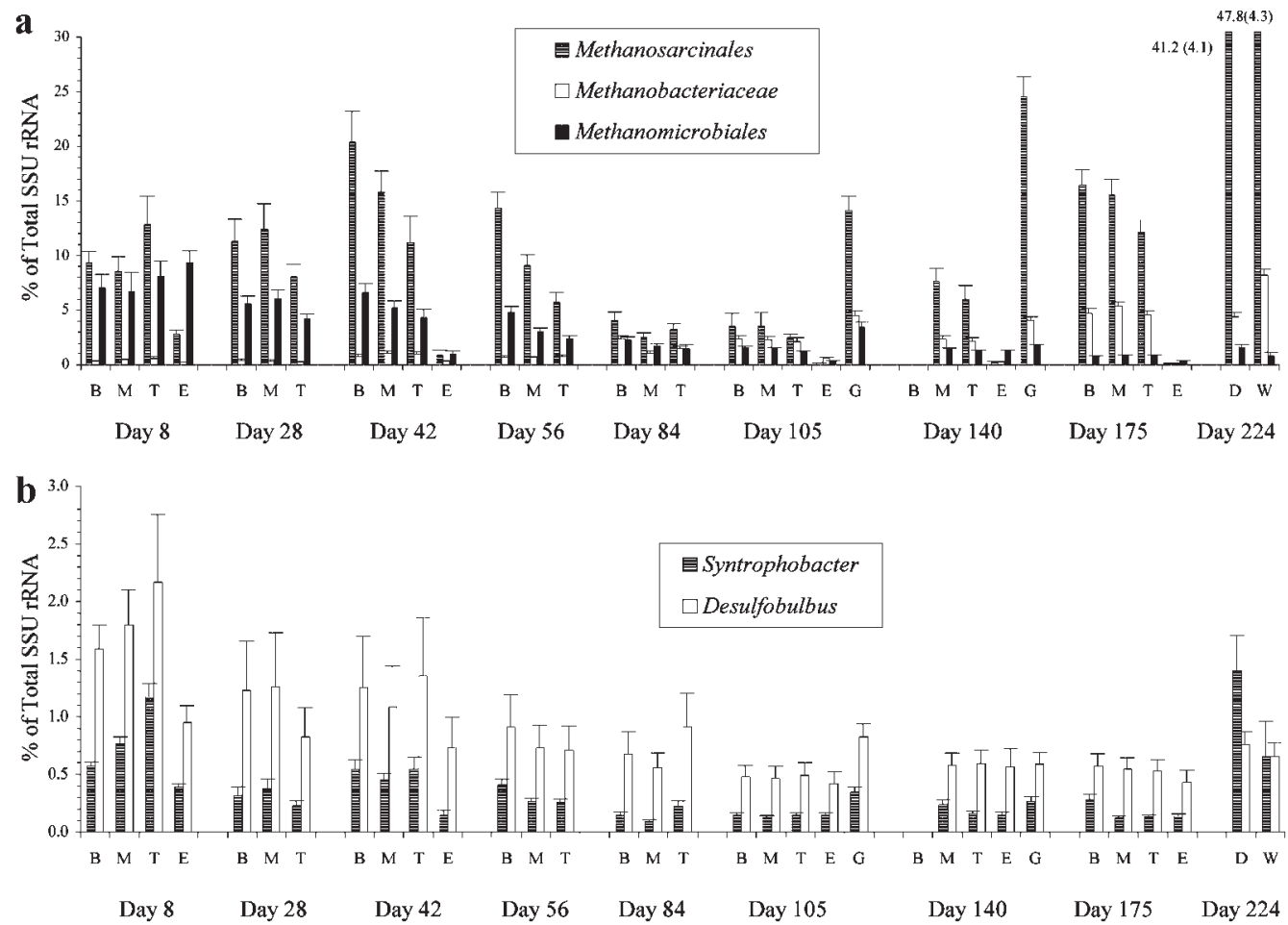

Reactor GP
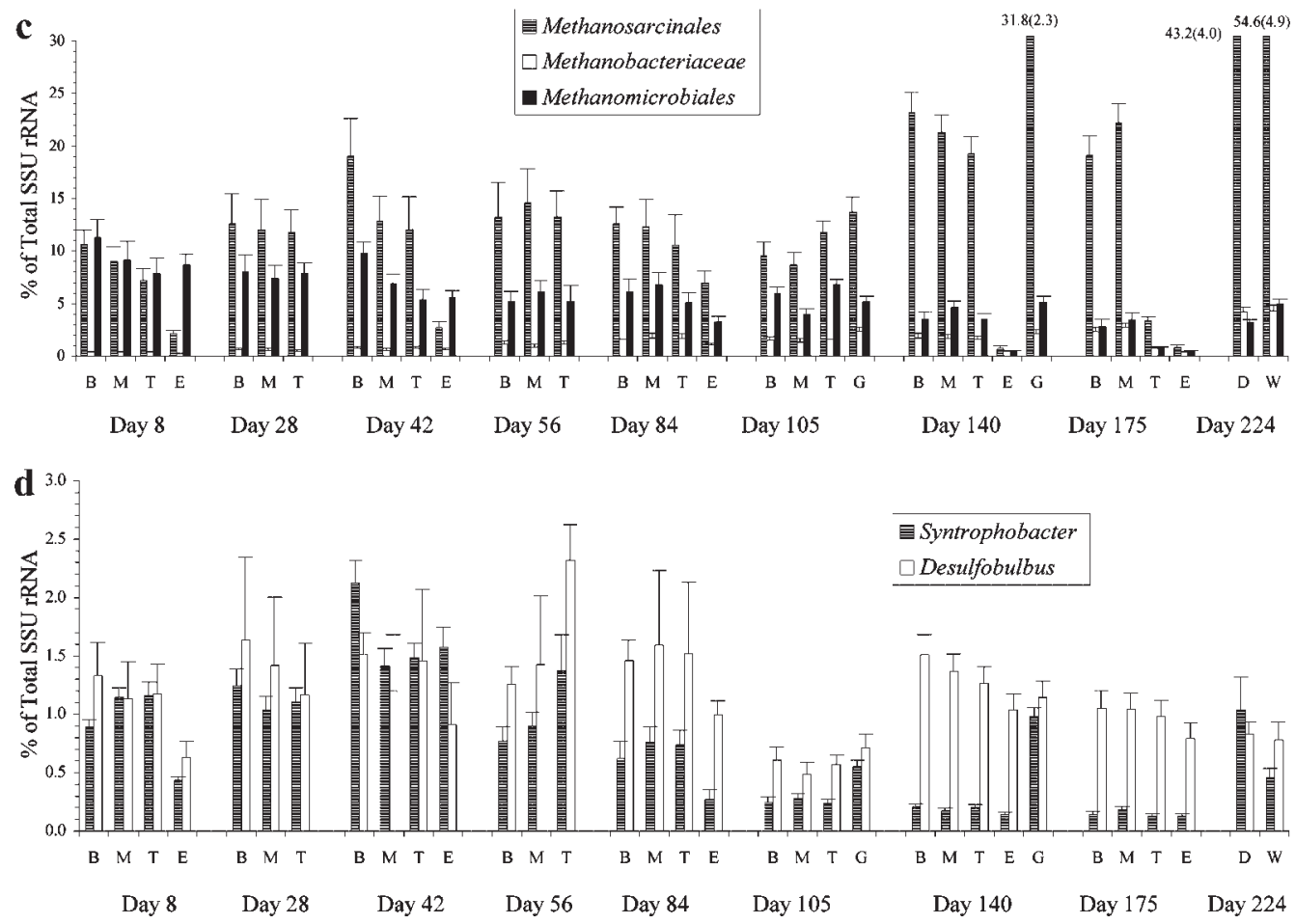

Figure 4. Comparison of microbial population levels for samples from different locations in the sludge bed, in the effluent, and in the granules: methanogens in reactor G (a) and reactor GP (c); Syntrophobacter and Desulfobulbus in reactor G (b) and reactor GP (d). Population SSU rRNA levels are expressed as indicated in legend to Figure 3. The labels by some of the bars indicate the SSU rRNA levels with standard deviations in parentheses. Data for the bottom of the sludge bed in reactor G on Day 140 were not determined. Sample nomenclature: B, bottom of the sludge bed; M, middle of sludge bed; T, top of the sludge bed; E, effluent; G, granular sludge; D, dark granules; and W, whitish granules. 


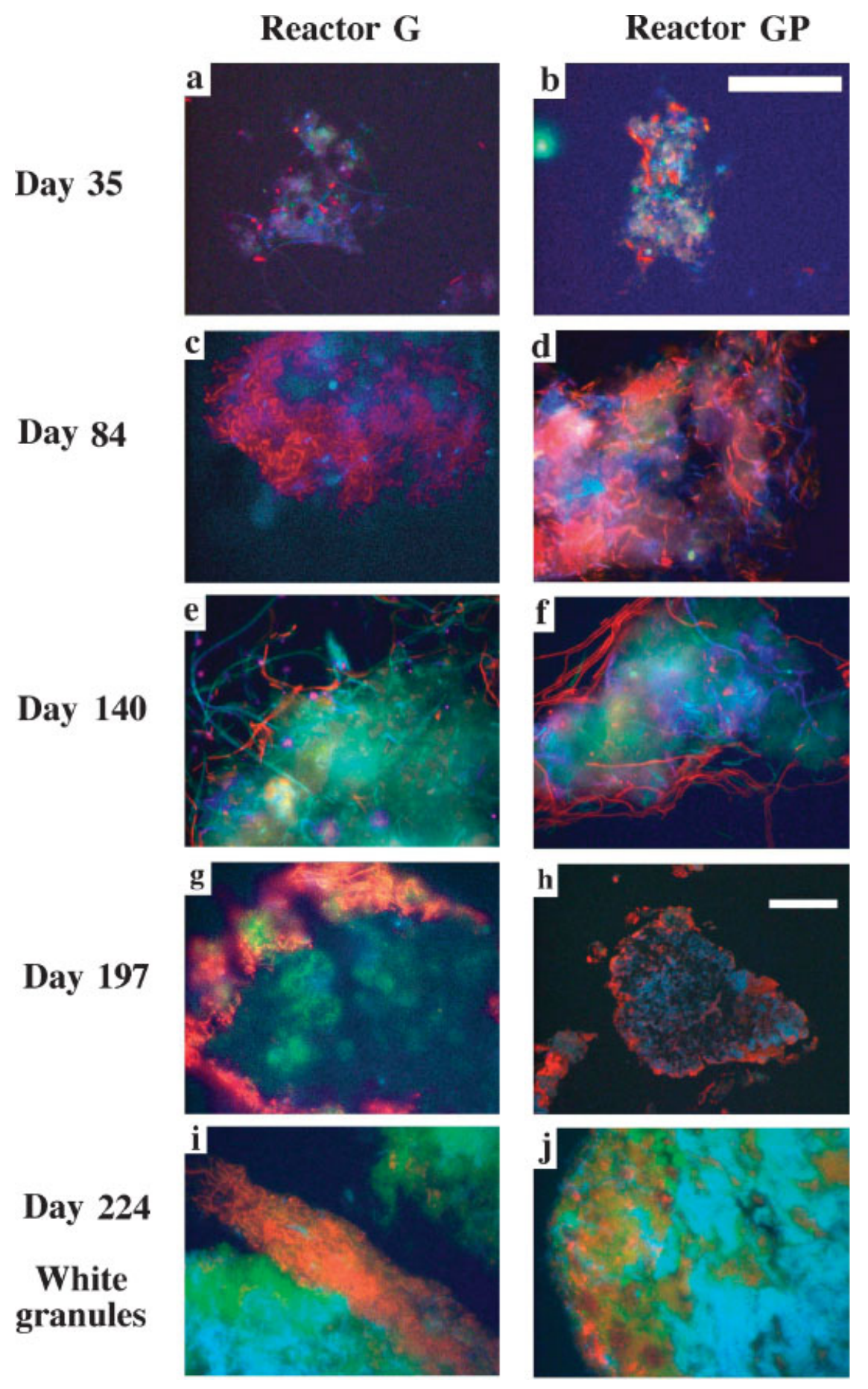

Figure 5. Typical epifluorescence images of cell aggregates from reactor $\mathrm{G}(\mathbf{a}, \mathbf{c}, \mathbf{e}, \mathbf{g}$, and $\mathbf{i})$ and reactor $\mathrm{GP}(\mathbf{b}, \mathbf{d}, \mathbf{f}, \mathbf{h}$, and $\mathbf{j})$ on days 35 (a and b), 84 (c and d), 140 (e and f), 197 ( $g$ and h), and whitish granules on day 224 ( $\mathrm{i}$ and j) hybridized with probes S-D-Arch-0915-a-A-20 (Archaea) labeled with Oregon Green (green), S-D-Bact-0338-a-A-18 (Bacteria) labeled with Cy3 (red), and S-S-M.con-0381-a-A-22 (M. concilii) labeled with Cy5 (blue). Bar for all images is given in $\mathrm{b}$ and is $50 \mu \mathrm{m}$, except for images $\mathrm{g}$ and $\mathrm{h}$, for which to the bar is given in $\mathrm{h}$ and is $=200 \mu \mathrm{m}$.

shown). At the end of the operating period, $M$. concilii SSU rRNA levels were approximately $25 \%$ for both reactors. In reactor G, Methanobacteriaceae constitued about $2 \%$ at the beginning of period 3 and gradually decreased to about $1 \%$ by the end of this period (Fig. 3c). In reactor GP the levels of Methanomicrobiales had decreased gradually to $1.5 \%$ by day 166 and then increased slightly to $2.8 \%$ by day 224 . The levels of Methanobacteriaceae remained relatively constant between days 119 and 166 in both reactors. By day 175, Methanobacteriaceae SSU rRNA had increased to $4.7 \%$ in reactor $\mathrm{G}$ and subsequently decreased slightly; whereas in reactor GP, the levels gradually increased to $2.8 \%$ by the end of the experiment (Fig. 3c and d). Methanobrevibacter spp. SSU rRNA remained below $1.5 \%$ in both reactors at all times, 
even when the Methanobacteriaceae levels increased substantially during the later phase of the experiment (Fig. 3c and d). Syntrophobacter spp. levels in both reactors remained low during period 3. Desulfobulbus spp. levels in reactor G were approximately $0.6 \%$ between days 119 and 164, and then increased to $1 \%$ at the end of the operating period (Fig. 3e). For reactor GP, these levels decreased from 1.8\% to approximately $1 \%$ between days 119 and 150 , and then remained around this level until the end of the operating period. The SSU rRNA levels of both Syntrophobacter spp. and Desulfobulbus spp. decreased as the volumetric loading rate and the apparent propionate removal in reactor GP increased (Fig. 1b and 3f).

The biomass over the bed height became more stratified during period 3 as compared to period 2. Methanosarcinales (mainly M. concilii) reached their highest levels in the bottom of the blanket as compared to the top of the blanket. On days 140 and 175 , levels of $M$. concilii were less than $1 \%$ in the effluent from both reactors, while their levels were $15 \%-$ $25 \%$ in the bottom part of the blanket. Syntrophobacter spp. and Desulfobulbus spp. levels were similar in the washed out biomass and in the biomass inside the reactors on days 140 and 175 (Fig. 4b and d).

The levels of Methanosarcinales were much higher in the granules than in the total biomass on days 140 and 224 (Fig. 4a and c). On day 224, their levels were above $40 \%$ in granules. Methanobacteriaceae and Methanomicrobiales levels were also slightly higher in granules than in the overall biomass. Syntrophobacter spp. levels were much higher in granules than in the total biomass as measured on day 140 . This was not the case for Desulfobulbus spp. (Fig. $4 \mathrm{~b}$ and d).

During period 3, granules were either packed loosely with many void areas (Fig. 5e and f) or packed tightly (Fig. 5g-j). These two types of granules usually appeared in the same reactor at the same time. However, there were more densely packed granules on day 224 than on day 105. At the end of the operating period (day 224), the majority of granules in both reactors were whitish. In addition, a few dark granules were observed. Samples of both dark and whitish granules were collected and the whitish granules contained only slightly higher levels of $M$. concilii and slightly lower levels of Syntrophobacter spp. than the dark granules (Fig. 4). Thus, membrane hybridization showed that the white and dark granules were similar in regards to the microbial population composition and, in addition, no apparent difference in granular structure was seen after investigation with FISH (Fig. $5 i$ and j). Granules from both reactors sampled on days 197 and 224 exhibited layered structures (Fig. 5g-j). Mostly, the observed granules contained a core consisting mainly of $M$. concilii cells and one to four thin layers. Although $M$. concilii were found to be predominant in the core area, some microcolonies of $M$. concilii were also found in the subsurface layer of syntrophic consortia (Fig. 5j).

The aggregate size decreased between days 119 and 140 (Fig. 2). The increased shear forces imposed during this period removed fermenting bacteria from the aggregates resulting in smaller aggregate sizes. During this period, the granules were embedded in the dispersed sludge blanket, indicating that granulation was not a uniform process involving all of the biomass. Granulation in both reactors was affected by the presence of fermenting bacteria, because a delay in the maturation phase of the granular blanket (i.e., a blanket with almost only granules) was observed, which occurred only around day 197 after washing out the bulk of the fermenting bacteria.

\section{DISCUSSION}

\section{Monitoring Granulation}

In this study, we monitored the progress of granulation by observing the microbial population dynamics and aggregate structure during granulation with membrane hybridization and FISH. Specifically, we investigated if $M$. concilii cells and syntrophic consortia serve as growth nuclei during granulation by operating two laboratory-scale UASB reactors. Reactor $\mathrm{G}$ was fed glucose and was operated to support the growth of M. concilii, while reactor GP was fed a mixture of glucose and propionate to favor a consortium of syntrophic microorganisms.

It should be noted that the propionate loading was substantially higher in reactor GP than in reactor $G$ as intended in the study. This was confirmed by performing metabolic activity tests using propionate as the substrate at the end of the experimental period, after the reactors had been exposed to overload conditions and a recovery period (Zheng, 1999). The propionate consuming activities in reactors $\mathrm{G}$ and GP were determined to be $0.46 \pm 0.06$ and $1.07 \pm 0.07 \mathrm{~g} \mathrm{COD} / \mathrm{g}$ VSS/day, respectively (Zheng, 1999).

\section{Methanosaeta spp. Serve as Growth Nuclei for Granule Initiation}

Between days 35 and 49, the aggregates increased considerably in size in both reactors, indicating that for both reactors the granulation phase had started. At the end of this period, $M$. concilii levels had reached $22.5 \%$ in reactor $\mathrm{G}$ and $21.1 \%$ in reactor GP, suggesting $M$. concilii played a key role in the increase in aggregate size. On days 35 and 49, it was shown with FISH that $M$. concilii cells were present throughout the aggregates and that they served as the structural backbone to allow attachment of other microorganisms. Thus, $M$. concilii served as growth nuclei for granule initiation. Subsequent monitoring of the granulation process with FISH showed that $M$. concilii remained present mostly in the core of the aggregates and granules for the rest of the operating time (Fig. 5). M. concilii population levels also were much higher in the granules than in the bulk biomass, except for reactor GP on day 105 (Fig. 4). Since Methanosaeta spp. do not have a higher growth rate than most bacteria and other archaea, the increase in the M. concilii population between startup and day 49 was likely due to their ability to remain in the reactor under the physical selection pressure imposed due to their 
high settling ability, while other bacteria and archaea were washed out.

\section{Syntrophic-Propionate Oxidizers May Help Granulation}

The aggregate sizes increased faster in reactor GP than in reactor $\mathrm{G}$ between days 35 and 49 (Fig. 2). Since the levels of Syntrophobacter spp. also increased during this period in reactor GP (and not in reactor G), the syntrophic consortia may have assisted the granulation process. It is unlikely, however, that species of Syntrophobacter and Desulfobulbus served as nuclei, since their population levels were low. The assistance in granulation may have resulted from them acting as "coating bacteria" attached to the $M$. concilii backbone (Uemura and Harada, 1993, 1995). In particular, this was the case for Syntrophobacter spp. since their levels were found to be higher in granules than in the bulk biomass, indicating that their selection strategy involved attachment to particles with a high settling ability. Such a selection strategy was not found for Desulfobulbus spp., since their levels in the granules and the bulk biomass were similar, indicating that not all of the microorganisms in the reactor have the ability to associate with granules. It should be noted that other populations, which were not detected by the probes for these two genera of propionate-oxidizing bacteria targeted in our study, may have played a role in oxidizing propionate in reactor GP, especially at the higher loading rates when the levels of Syntrophobacter spp. and Desulfobulbus spp. were low compared to their levels observed during period 1 .

FISH results further supported the hypothesis that syntrophic bacteria helped granulation by attaching to the M. concilii backbone: a layer composed of juxtaposed bacteria and archaea was found around the $M$. concilii core (especially for granules from reactor GP) (Fig. 5h). Since propionate accounted for $40 \%$ of the influent COD in this reactor, it is likely that this layer contained high levels of propionate-oxidizing syntrophic consortia. The structure of granules observed in reactor GP is consistent with the model of Guiot et al. (1992), which described that syntrophic consortia form a subsurface layer in a granule. However, this is different from some previous reports in which syntrophic consortia were usually found to form isolated microcolonies in granules (Fang et al., 1995; Grotenhuis et al., 1991; Harmsen et al., 1996a,b). A layer of juxtaposed bacteria and archaea was also found in granules from reactor G (Fig. 5g).

\section{Filamentous Bacteria Delay Maturation of Granular Blanket}

Between days 49 and 70, the increases in biomass levels were associated with decreases in the levels of predominant methanogens in both reactors and of acetogens in reactor $\mathrm{G}$. FISH with a bacterial probe demonstrated that increases in filamentous bacteria, which were usually free-living with a low settling ability, caused the increases in biomass. They were abundant in the washed out biomass as well as in the upper parts of the reactors above the sludge blankets. The increases in biomass levels in the reactor and effluent were larger in reactor $\mathrm{G}$ than in reactor GP, since glucose accounted for $100 \%$ of the COD in the influent for reactor $\mathrm{G}$ and only for $60 \%$ for reactor GP. Higher levels of filamentous bacteria in reactor $\mathrm{G}$ than in reactor GP resulted in lower relative levels of $M$. concilii in reactor $\mathrm{G}$ than reactor GP. The filamentous bacteria accumulated in the system despite their low settling ability, because of their high growth rates. These fast-growing bacteria are commonly seen in anaerobic systems fed a carbohydrate-rich wastewater; and once they reach large quantities their levels must be controlled (Fukuzaki et al., 1991). As demonstrated in this study, a high F:M ratio can cause excessive growth of fermenting bacteria and upset the proper balance between the three major trophic groups of anaerobic microorganisms. This upset can cause a decrease in the relative abundance of key microorganisms, leading to a deterioration of granulation and, in addition, can cause bulking.

Increasing the shear forces in the reactor by increasing the recycling rate circumvented accumulation of fermenting bacteria in the reactor. This improved the settling ability of aggregates, increased biomass levels, and secured maturation of the granular blanket. Further increases in the recycling rates were necessary between days 152 and 224 to prevent the proliferation of fermenting bacteria after increases in the F:M ratio due to increases in the volumetric loading rate.

\section{Life-Cycle of Granules}

Based on the results of this study and information from the literature, the steps involved in the development of a granular blanket in a UASB reactor treating readily degradable substrates, such as glucose, can be summarized as follows. During the acclimation phase, aggregate formation starts from nuclei of $M$. concilii cells. Subsequently, other cells, which constitute syntrophic consortia, immobilize on the nuclei and form a "coat" that is required to further increase the size of the aggregates. Therefore, the presence of syntrophic consortia enhances granulation, which is agreement with El-Mamouni et al. (1997). The newly formed aggregates are packed loosely during the acclimation and granulation phases, and change into tightly-packed granules when the embedded cells multiply and the granules mature. Eventually, the growth of mature granules proceeds like the growth of tree trunk with new layers developing around the old layers of cells. New layers start with a mixture of cells from different trophic groups. Initially, the new layer is dominated by fermenting bacteria due to their accessibility to readily degradable substrate. When the layer matures and becomes thicker, fermenting bacteria that are located furthest in the layer gradually decay due to mass transfer limitation of substrate, leaving the acetogens and methanogens to become dominant. The decay of fermenting bacteria can also leave void areas for methanogens and syntrophic consortia to develop 
microcolonies. As more layers form, the granules become larger in size. When granules become so large that intermediate substrates cannot transfer to the cells in the core such cells decay, resulting in granules with void centers. Large void centers reduce the granular strength, which results in breakage of granules. New layers can subsequently attach to these granular pieces resulting in a new generation of granules.

In this study, granules formed in both reactors contained a surface layer dominated by filamentous bacteria (Fig. 5i). Some archaeal cells, including $M$. concilii, were also found in these surface layers (Fig. 5j). This finding is consistent with observations that Methanosaeta spp. formed microcolonies side by side with syntrophic microcolonies (Harmsen et al., 1996b). The presence of filamentous bacteria on the surface of granules was also reported for granules fed sucrose (Uemura and Harada, 1995) or glucose (Wu et al., 1993). Others have suggested that filaments form a thin layer on the surface of granules, which helps to keep other microorganisms in place, and therefore are important for granulation (Sekiguchi et al., 1999). In the present study, however, the surface layers were often not firmly attached to the granules and in some areas the inner layers were exposed. In addition, archaea were often exposed to the bulk liquid and visible on the outside of the granules (Fig. 5j).

\section{Methanobrevibacter spp. May be not as Important as Thought for Granulation}

Methanobrevibacter spp. are frequently reported to be the major hydrogenotrophic methanogens that form microcolonies inside granules with syntrophic bacteria (Fang et al., 1995; Grotenhuis et al., 1991; Harmsen et al., 1996b; Wu et al., 1991). Methanobrevibacter spp. also are believed to be important in granulation due to their ability to secrete extracellular polymers (ECP) (Samsoon et al., 1987, 1990). In the current study, Methanobrevibacter spp. SSU rRNA remained below $1.5 \%$ in both reactors, even when the Methanobacteriaceae levels increased considerably during the later phase of the experiment (Fig. 3c and d). Thus, Methanobacteriaceae other than Methanobrevibacter spp. or novel Methanobrevibacter spp. not targeted by probe S-GMbvb-0406-a-A-22 must have been responsible for these increases. Furthermore, when Syntrophobacter SSU rRNA increased from $0.3 \%$ to $2.1 \%$ in reactor GP for the first 21 days, Methanobrevibacter spp. remained low. This indicates that Methanobrevibacter spp. targeted in this study were not important in the syntrophic relationship with Syntrophobacter spp. and that their involvement in the granulation process was unlikely. On the other hand, the levels of Methanomicrobiales were higher in reactor GP than in reactor $G$ throughout the experiment, which may indicate they were involved in syntrophic relationships with Syntrophobacter spp. Consistent with this, Harmsen et al. (1996a) reported that Methanospirillum spp., which are members of the Methanomicrobiales, were involved in syntrophic relationships in granules.

\section{CONCLUSIONS}

The recommended startup strategy for UASB reactors involves gradually increasing the loading rate in order to wash out poorly settling biomass and initiate aggregate formation, while maintaining an acetate concentration below $200 \mathrm{mg} / \mathrm{L}$ to encourage the growth of Methanosaeta spp. In this study, we used this startup strategy combined with the addition of propionate (reactor GP) to evaluate if granulation starts from the aggregation of Methanosaeta cells and/or from nuclei containing syntrophic consortia. We demonstrated that the recommended startup strategy for UASB reactors encouraged the growth of $M$. concilii. During the acclimation and granulation phase (i.e., initial formation of aggregates and further size increase of granules), we observed numerous aggregates with $M$. concilii in the core. In contrast, levels of Syntrophobacter and Desulfobulbus remained low in both reactors, their settling ability was low, and they were not found in the core of aggregates during acclimation and granulation phases. Thus, granulation started with $M$. concilii cells as growth nuclei and not with syntrophic consortia. However, Syntrophobacter spp. were enriched in the biomass of both reactors by attachment to the $M$. concilii backbone and this enhanced the granulation process resulting in larger granules in reactor GP than in reactor $\mathrm{G}$.

This study demonstrated also that the growth of fermenting bacteria should be controlled to maintain high levels of $M$. concilii when the wastewater contains readily degradable substrates, such as glucose. The presence of high levels of fermenters delayed the start of the maturation phase of granulation due to the washout of $M$. concilii aggregates that where covered by fermenters with a low settling ability. The coverage with fermenters reduced the selective advantage that microorganisms in aggregates have over dispersed microorganisms. We decreased the volumetric loading rate when excessive biomass loss was observed to reduce the proliferation of fermeneters. In addition, we applied a high recycle rate to remove the excess of fermenting bacteria from the aggregates by shear. Close monitoring of microbial population levels during startup can provide the necessary information for adjusting the startup strategy and to insure the predominance of key microorganisms for granulation.

\footnotetext{
We are thankful to Vicki Swidron for help with reactor maintenance and chemical analyses. This research was supported by the Center for Advanced Study and the Critical Research Initiative of the University of Illinois.
}

\section{References}

Alm EW, Zheng D, Raskin L. 2000. The presence of humic substances and DNA in RNA extracts affects hybridization results. Appl Environ Microbiol 66(10):4547-4554.

Alphenaar A. 1994. Anaerobic granular sludge: Characterization, and factors affecting its functioning [Ph. D. thesis]. Wageningen, The Netherlands: Wageningen Agricultural University. 222p. 
Amann RI, Krumholz L, Stahl DA. 1990. Fluorescent-oligonucleotide probing of whole cells for determinative, phylogenetic, and environmental studies in microbiology. J Bacteriol 172(2):762-770.

Amann RI, Zarda B, Stahl DA, Schleifer KH. 1992. Identification of individual prokaryotic cells by using enzyme labeled, ribosomal RNA targeted oligonucleotide probes. Appl Environ Microbiol 58(9):3007-3011.

Anderson GK, Yang G. 1992. Determination of bicarbonate and total volatile acid concentration in anaerobic digesters using a simple titration. Water Environ Res 64:53-59.

Angenent LT, Sung S, Raskin L. 2004. Formation of granules and Methanosaeta fibres in an anaerobic migrating blanket reactor (AMBR). Environmen Microbiol 6(4):315-322.

APHA. 1995. Standard methods for the examination of water and wastewater, 19th edn. Washington, DC: American Public Health Association.

Boone DR, Whitman WB, Rouvière P. 1993. Diversity and taxonomy of methanogens. In: Ferry J, editor. Methanogenesis: Ecology, physiology, biochemistry \& genetics. New York: Chapman \& Hall. pp 35-80.

de los Reyes FL, Ritter W, Raskin L. 1997. Group-specific small subunit rRNA hybridization probes to characterize filamentous foaming in activated sludge system. Appl Environ Microbiol 63(3):1107-1117.

Devereux R, Kane MD, Wilfrey J, Stahl D. 1992. Genus- and group-specific hybridization probes for determinative and environmental studies of sulfate-reducing bacteria. Syst Appl Microbiol 15:601-609.

Dubourguier HC, Prensier G, Albagnac G. 1988. Structure and microbial activities of granular anaerobic sludge. In: Lettinga G, Zehnder AJB, Grotenhuis JTC, Hulshoff Pol LW, editors. Granular aerobic sludge: microbiology and technology. Lunteren: Pudoc Wageningen. pp 18-33.

Ehrlich GG, Goerlitz DF, Bourell JH, Eisen GV, Godsy EM. 1981. Liquid chromatography procedure for fermentation product analysis in the identification of anaerobic bacteria. Appl Environ Microbiol 42:878-885.

El-Mamouni R, Leduc R, Guiot SR. 1997. Influence of the starting microbial nucleus type on the anaerobic granulation dynamics. Appl Microbiol Biotechnol 47(2):189-194.

Fang HHP, Li YY, Chui HK. 1995. Performance and sludge characteristics of UASB process treating propionate-rich waste-water. Water Res 29(3):895-898.

Fukuzaki S, Chang YJ, Nishio N, Nagai S. 1991. Characteristics of granular methanogenic sludge grown on lactate in a UASB reactor. J Fermentat Bioeng 72(6):465-472.

Griffin ME, McMahon KD, Mackie RI, Raskin L. 1998. Methanogenic population dynamics during start-up of anaerobic digesters treating municipal solid waste and biosolids. Biotechnol Bioeng 57(3):342-355.

Grotenhuis JT, Koornneef E, Plugge CM. 1988. Immobilization of anaerobic bacteria in methanogenic aggregates. In: Lettinga G, Zehnder AJB, Grotenhuis JTC, Hulshoff Pol LW, editors. Granular aerobic sludge: microbiology and technology. Lunteren: Pudoc Wageningen. pp 42-47.

Grotenhuis JT, Smit M, Plugge CM, Xu YS, van Lammeren AA, Stams AJ, Zehnder AJ. 1991. Bacteriological composition and structure of granular sludge adapted to different substrates. Appl Environ Microbiol 57(7):1942-1949.

Grotenhuis JTC, Plugge CM, Stams AJM, Zehnder AJB. 1992. Hydrophobicities and electrophoretic mobilities of anaerobic bacterial isolates from methanogenic granular sludge. Appl Environ Microbiol 58(3): $1054-1056$.

Guiot SR, Pauss A, Costerton JW. 1992. A structured model of the anaerobic granule consortium. Water Sci Technol 25(7):1-10.

Harmsen HJ, Akkermans AD, Stams AJ, de Vos WM. 1996a. Population dynamics of propionate-oxidizing bacteria under methanogenic and sulfidogenic conditions in anaerobic granular sludge. Appl Environ Microbiol 62(6):2163-2168.

Harmsen HJ, Kengen HM, Akkermans AD, Stams AJ, de Vos WM. 1996b. Detection and localization of syntrophic propionate-oxidizing bacteria in granular sludge by in situ hybridization using 16S rRNA-based oligonucleotide probes. Appl Environ Microbiol 62(5):1656-1663.

Hulshoff Pol LW. 1989. The phenomenon of granulation of anaerobic sludge [Ph. D.]. Wageningen, The Netherlands: Wageningen University (formely Agricultural University Wageningen). 120p.
Hulshoff Pol LW, de Zeeuw WJ, Velzeboer CTM, Lettinga G. 1983. Granulation in UASB-reactors. Water Sci Technol 15:291304.

Huser A, Wuhrmann K, Zehnder A. 1982. Methanothrix soehngenii gen. nov. spec. nov., a new acetotrophic non-hydrogen-oxidizing methane bacterium. Arch Microbiol 132:1-9.

Jhung JK, Choi E. 1995. A comparitive study of UASB and anaerobic fixed film reactors with development of sludge granulation. Water Res 29(1):271-277.

Kamagata Y, Mikami E. 1990. Some characteristics of 2 morphotypes of Methanothrix soehngenii from mesophilic anaerobic digesters. J Fermentat Bioeng 70(4):272-274.

Lettinga G. 1995. Anaerobic digestion and wastewater treatment systems. Antonie van Leeuwenhoek 67:3-28.

Macleod FA, Guiot SR, Costerton JW. 1990. Layered structure of bacterial aggregates produced in an upflow anaerobic sludge bed and filter reactor. Appl Environ Microbiol 56(6):1598-1607.

McMahon KD, Stahl DA, Raskin L. 1998. A comparison of the use of in vitro-transcribed and native rRNA for the quantification of microorganisms in the environment. Microb Ecol 36(3):362-371.

Morgan JW, Evison LM, Forster CF. 1991a. The internal architecture of anaerobic sludge granules. J Chem Technol Biotechnol 50(2):211226.

Morgan JW, Evison LM, Forster CF. 1991b. Upflow sludge blanket reactors - The effect of bio-supplements on performance and granulation. J Chem Technol Biotechnol 52(2):243-255.

Morvai L, Mihaltz P, Czako L, Hollo J. 1991. Application of UASB-reactors in industrial wastewater treatment: Performance data and results in granulation control. ACTA Biotechnologica 11:409-418.

Mulder R, Simons B, Verkuijlen J, Demattos MJT, Neijssel OM. 1989. Biomass retention in a glucose acidifying anaerobic gas-lift reactorIsolation of the organism responsible for granule formation. Appl Microbiol Biotechnol 30(6):641-646.

Raskin L, Poulsen LK, Noguera DR, Rittman BE, Stahl DA. 1994a. Quantification of methanogenic groups in anaerobic biological reactors by oligonucleotide probe hybridization. Appl Environ Microbiol 60(4): $1241-1248$.

Raskin L, Stromley JM, Rittmann BE, Stahl DA. 1994b. Group-specific 16S rRNA hybridization probes to describe natural communities of methanogens. Appl Environ Microbiol 60(4):1232-1240.

Raskin L, Capman WC, Kane MD, Rittmann BE, Stahl DA. 1996. Critical evaluation of membrane supports for use in quantitative hybridizations. Appl Environ Microbiol 62(1):300-303.

Raskin L, Capman WC, Sharp R, Poulsen LK, Stahl DA. 1997. Molecular ecology of gastrointestinal ecosystems. In: Mackie RI, White BA, Isaacson RE, editors. Gastrointestinal microbes: Gastrointestinal microbiology and host interactions. New York, NY: Champman \& Hall. pp 243-298.

Samsoon PALNS, Loewenthal RE, Dold PL, Marais G. 1987. Hypothesis for pelletisation in the upflow anaerobic sludge bed reactor. Water Sa 13(2):69-80.

Samsoon PALNS, Loewenthal RE, Wentzel MC, Marais G. 1990. Effect of nitrogen limitation on pelletization in upflow anaerobic sludge bed (UASB) systems. Water Sa 16(3):165-170.

Scherer P. 1983. Separation of bacteria from a methanogenic population wastewater population by utilizing a self-generating percoll gradient. J Appl Bacterial 55:481-486.

Schmidt JE, Ahring BK. 1996. Granular sludge formation in upflow anaerobic sludge blanket (UASB) reactors. Biotechnol Bioeng 49:229-246.

Sekiguchi Y, Kamagata Y, Nakamura K, Ohashi A, Harada H. 1999. Flourescence in situ hybridization using 16S rRNA-targetted oligonucleotides reveals localization of methanogens and selected uncultured bacteria in mesophilic and thermophilic sludge granules. Appl Environ Microbiol 65:1280-1288.

Stahl DA, Amann RI. 1991. Development and application of nucleic acid probes. In: Stackebrandt E, Goodfellow M, editors. Nucleic acids techniques in bacterial systematics. New York: John Wiley \& Sons, Inc. pp 205-248. 
Uemura S, Harada H. 1993. Microbial characteristics of methanogenic sludge consortia developed in thermophilic UASB reactors. Appl Microbiol Biotechnol 39(4-5):654-660.

Uemura S, Harada H. 1995. Inorganic composition and microbial characteristics of methanogenic granular sludge grown in a thermophilic upflow anaerobic sludge blanket reactor. Appl Microbiol Biotechnol 43(2):358-364.

Vanderhaegen B, Ysebaert E, Favere K, van Wambeke M, Peeters T, Pánic V, Vandenlangenbergh V, Verstraete W. 1992. Acidogenesis in relation to in-reactor granule yield. Water Sci Technol 25(7): $21-30$.

Wiegant WM. 1988. The "spaghetti theory" on anaerobic granular sludge formation, or the inevitability of granulation. In: Lettinga G, Zehnder AJB, Grotenhuis JTC, Hulshoff Pol LW, editors. Xxxx. Lunteren: Pudoc Wageningen. pp 146-152.

Wiegant WM, de Man AWA. 1986. Granulation of biomass in thermophilic upflow anaerobic sludge blanket reactors treating acidified wastewaters. Biotechnol Bioeng 28:718-727.

Wiegant WM, Lettinga G. 1985. Thermophilic anaerobic digestion of sugars in upflow anaerobic sludge blanket reactors. Biotechnol Bioeng 27:1603-1607.

Wolin EA, Wolin MJ, Wolfe RS. 1963. Formation of methane by bacterial extracts. J Biol Chem 238:2882-2886.
Wu WM, Hickey RF, Zeikus JG. 1991. Characterization of metabolic performance of methanogenic granules treating Brewery waste-waterRole of sulfate-reducing bacteria. Appl Environ Microbiol 57(12): 3438-3449.

Wu WM, Thiele JH, Jain MK, Pankratz HS, Hickey RF, Zeikus JG. 1993. Comparison of rod-type versus filament-type methanogenic granulesMicrobial-population and reactor performance. Appl Microbiol Biotechnol 39(6):795-803.

Wu WM, Jain MK, Zeikus JG. 1996. Formation of fatty acid-degrading, anaerobic granules by defined species. Appl Environ Microbiol 62(6):2037-2044.

Zehnder AJB, Huser BA, Brock TD, Wuhrmann K. 1980. Characterization of an acetate-decarboxylating, non-hydrogen-oxidizing methane bacterium. Arch Microbiol 124:1-11.

Zheng D. 1999. Evaluation of granulation processes in upflow anaerobic sludge blanket reactors using oligonucleotide probe hybridizations [Ph.D.]. Urbana, IL: University of Illinois at Urbana-Champaign.

Zheng D, Raskin L. 2000. Quantification of Methanosaeta species in anaerobic bioreactors using genus- and species-specific hybridization probes. Microbial Ecol 39:246-262.

Zheng D, Alm EW, Stahl DA, Raskin L. 1996. Characterization of universal small-subunit rRNA hybridization probes for quantitative molecular microbial ecology studies. Appl Environ Microbiol 62:4504-4513. 